\title{
THE NATURE OF FAITH IN ISAIAH OF JERUSALEM ${ }^{1}$
}

\author{
G.C.I. Wong
}

This dissertation explores two questions related to the theme of faith and trust in Yahweh. First, what did Isaiah expect faith to entail? Was faith understood negatively in terms of a rejection of all human resources, be they alliances with foreign nations or one's own defence preparations? Or was the faith he proclaimed a positive call for fortitude and courage in the face of battle? Second, did Isaiah's faith consist of an unswerving belief in Jerusalem's absolute and unconditional inviolability? Or did his faith envisage the possibility of Jerusalem's destruction?

On the question whether faith implied human passivity, there is little evidence to think that, for Isaiah, faith was opposed to human resourcefulness or defensive preparations. Nor is it correct to say that he was opposed to all forms of human politics. Rather, faith primarily involved believing Yahweh's words and observing his commands with respect to righteousness and justice. The key passages discussed in this regard are 7:1-17, 22:1-14, 28:14-18, 30:15-17 and 31:1-4. These passages have sometimes been used to imply that faith for Isaiah involved the 'passionate elimination of all reliance on oneself' (G. von Rad, Old Testament Theology [vol. 2; London, 1975] 160). Similarly, I reject the dichotomy between 'a faith that means believing' and 'a faith that means doing' (S.H. Blank, Prophetic Faith in Isaiah [London, 1958] 34ff). To trust in Yahweh, to depend on him, to return to him, to show repentance, to believe in him, and to practise truthfulness, righteousness and justice, are all closely related actions in

${ }^{1}$ G.C.I. Wong, The Nature of Faith in Isaiah of Jerusalem (Unpublished Ph.D. Thesis, University of Cambridge, 1995); supervisors: Professors H.G.M. Williamson and J.A. Emerton. 
Isaiah. Consequently, a distinction between a faith that trusts and a faith that acts ethically is improbable in Isaiah. If a synthesis is required, it may be suggested that faith, for Isaiah, meant maintaining a proper and correct relationship with Yahweh. Naturally, such a proper relationship would involve trusting in the reliability of Yahweh's words and promises (7:49), as well as seeking to obey his instructions on justice and righteousness (22:14; 30:12ff). Faith and trust in Yahweh is thus closely connected to the practice of justice and righteousness in society.

In exploring the question whether Isaiah's faith made him certain that Jerusalem would never be destroyed, the discussion examines two related topics: the so-called doctrine of Zion's inviolability and Isaiah's attitude to Assyria, the dominant world power of his time. Many scholars cite certain passages as evidence for Isaiah's belief in Zion's absolute inviolability while many others equally deny the authenticity of these same passages, concluding that Isaiah did not believe in any doctrine of Zion's invincibility. The passages in question (8:9-10; 17:12-14; 14:28-32; 29:1-8) do not, however, provide any firm evidence for belief in such a doctrine, whether or not one regards them as Isaianic. With respect to passages which concern Isaiah's attitude towards Assyria (10:5-34; 5:26-30; 8:5$8 ; 14: 24-27 ; 30: 27-33 ; 31: 5-9)$, he clearly regarded Assyria as Yahweh's means of bringing punishment upon Judah and Jerusalem, and his words of judgement certainly imply the defeat, and possibly even destruction, of Zion. The verses which, just as clearly, speak of Yahweh's judgement and destruction of Assyria, do not necessarily imply the preservation of Zion from destruction and disgrace. Therefore, while Isaiah certainly believed in the safety of Zion against the Syro-Ephraimitic attack (7:2-16), there is no reason to suppose that he upheld a doctrine of Zion's absolute inviolability. If this judgement is sound, then it is incorrect to suggest that Isaiah, unlike Micah, could not conceive of Zion's destruction, as some have suggested (e.g. von Rad, Theology, 164). Nor is it fair to say (with W.L. Holladay, Isaiah: Scroll of a Prophetic Heritage [Grand Rapids, 1978] 121) that it was Isaiah's stress on Zion's inviolability that Jeremiah needed to counteract (Je. 7:4). 
But if Isaiah clearly spoke of judgement on Judah, and even envisaged the possibility of Zion's destruction, does this mean that he was a prophet only of doom? Following a defence of the authenticity of more hope-filled passages (9:1-6; 11:1-5; $32: 1-4)$, I argue that Isaiah almost certainly spoke of more positive things for the future. He cannot therefore be classified simply as either a prophet of doom or one of hope. Isaiah still held out hope for a future Zion, founded on faith and righteousness, which would arise sometime after judgement (28:16; cf. 1:26; 11:1ff).

I suggest that labels such as 'pacifist', 'anti-political', 'politically neutral', 'prophet of doom' and 'prophet of hope' are, at best, misleading. For Isaiah, faith involved maintaining a right relationship with Yahweh-relationship which was characterised by trust and obedience. Where such faith was present, there was always hope for the future. Where it was absent, there was always cause to fear the worst. Isaiah's ministry was largely directed at a leadership which lacked this faith, and, consequently, his message is predominantly one of judgement. However, perhaps because he himself maintained faith in Yahweh, Isaiah hoped for a future beyond judgement in which Zion would once again be characterised by faithfulness (cf. 1:21-26). 